\title{
SZÍJHAJTÁSOK DINAMIKAI MODELLJÉNEK EGY LEHETSÉGES KIEGÉSZÍTÉSE
}

\author{
Fülöp Zsombor \\ PhD hallgató, Miskolci Egyetem, Szerszámgépészeti és Mechatronikai Intézet, \\ Szerszámgépek Intézeti Tanszéke \\ 3515 Miskolc, Miskolc-Egyetemváros, e-mail: fulop.zsombor@uni-miskolc.hu \\ Szilágyi Attila \\ egyetemi docens, tanszékvezetö, Miskolci Egyetem, Szerszámgépészeti és Mechatronikai Intézet, \\ Szerszámgépek Intézeti Tanszéke \\ 3515 Miskolc, Miskolc-Egyetemváros, e-mail:szilagyi.attila@uni-miskolc.hu
}

\begin{abstract}
Absztrakt
Ezen cikk a szijhajtások dinamikai modellezésével foglalkozik, amelynél egy lehetséges modellkiegészitési ötletet kivánunk bemutatni. Ismeretes, hogy a különbözö típusú szijjakkal (laposszij, Poli-V szíj, fogasszijj, ékszij stb.) tervezett szíjhajtások különbözö módon viselkednek, avagy valószinüleg különbözö instabilitási tartománnyal bírnak azonos szabad szijág tervezési paraméterek mellett. Ez föképp indokolja az eddigi modellek pontositását, amelyeknél csupán a transzverzális lengésre képes szabad szijágat vették figyelembe egy teljes rendszerként.
\end{abstract}

Kulcsszavak: szijhajtás, föhajtómü, dinamikai vizsgálat, szijágak transzverzális lengései

\begin{abstract}
This paper investigates the dynamical modelling of the belt drives, where we wish to introduce an idea of a possible new supplementation. As we know that, different type of belts (flat belts, poli-V belts, timed belts, V-belts, etc.) that are designed into the considered drivelines, show different dynamical behaviour, maybe have different instability ranges beside the same design parameters as well. This is the main reason why this supplementation is well-founded, because the former literatures took into consideration only the system of free belt itself as the complete system.
\end{abstract}

Keywords: belt drives, main drives, dynamical analysis, transversal vibration of the free belts

\section{Bevezetés}

A szíjhajtások rendkívül széles körben alkalmazhatók sok előnyük miatt [7, 16]. Ezen területen elért eredmények tehát rendkívül hasznosak lehetnek. A továbbiakban viszont inkább a szerszámgépeken alkalmazott szíjhajtásokon keresztül kívánjuk az olvasót bevezetni - egyrészt annak érdekében -, hogy a hajtástechnikában jártas mérnökök türelmét ne tegyük próbára. [4].

A nagypontosságú egyetemes szerszámgépeknek többnyire háromféle föorsó meghajtása létezik

A direkt meghajtás esetén nincs jelen szíjhajtás a kinematikai láncban, és/vagy közvetlenül a motor tengelyközéppontja a főorsó tengelyközéppontjával esik egybe. Fő hátránya ennek a hajtásnak, hogy a szíjrezgésektől mentes ugyan, de nem tud létrejönni hö leválasztás a villamos motor és a főorsó csapágyak között. 
A szijhajtással kombinált főhajtások esetében a motortól érkező, főleg az elektromos áram okozta hőmennyiséget a szíj nem vezeti át anyagtulajdonságából adódóan a főhajtásra. További előnye, hogy villamos hajtómotornak megfelelő lehet bármilyen általános célra megfelelő villamos motor - szerkezeti felépítéséből adódóan: többek között nincsen szükség csőszerủ tengelyre a villanymotor szempontjából, továbbá a megfelelő áttételek egyszerűen megvalósíthatók, így maga a gép felépítése is egyszerü.

A tehermentesített, szijjhajtással kombinált főhajtás esetében lehetőség adódik a szijfeszítő erő főorsótól való távoltartására is. Legelterjedtebb a laposszíjas és az ékszíjas hajtás.

Előnyként említhető általánosan a laposszíjhajtás esetében a kismértékü zajkeltő hatás; a terhelésből származó impulzusokat a szíjágak felveszik, tompítják, annak energiáját részben elnyelik. Összehasonlítva a fogaskerékhajtással, fogaskerék hajtómüvekkel - sokkal gazdaságosabb megoldás, egyszerübb kialakítással. Fenntartási rendszer szempontjából csupán egyetlen dologra kell figyelemmel lennünk, a tengelycsapágyak megfelelő kenésére egy egyszerübb kialakítású gép esetén is. Széleskörüen felhasználható azonos vagy ellentétes irányban forgó tengelyeknél, esetleg egymáshoz képest szöget bezáró tengelyeknél is. Az áthidalható tengelytávolság sokkal nagyobb értékü lehet (amely mellette még nagyon könnyen változtatható is), mint a fogaskerék hajtómüvek esetében, melynek kihasználása a legelső transzmissziós hajtásoknál figyelhető meg leginkább [7, 16].

Nagyteljesítményủ megmunkáló gépeknél manapság is használnak szíjhajtásokat főorsó meghajtásként, amennyiben csak a szerszámgépek témakörére kívánunk szorítkozni. Ahhoz, hogy a fentebb említett előnyeit a szíjhajtásoknak biztonsággal lehetőségünk legyen kihasználni, szükség van a fö hátrányának kiküszöbölésére, ez pedig a dinamikai érzékenység. Gondos, és az idő előrehaladtával egyre gondosabb dinamikai vizsgálatot érdemes végezni a szabad szíjágra és - az általam a mechanikai modellbe bevezetni kívánt - a szíjtárcsa mentén lévő szíj alkotta rezgőrendszerre már a hajtás tervezési szakaszában. Ismeretes, hogy a különböző típusú szíjakkal (laposszíj, Poli-V szíj, fogasszíj, ékszíj, stb.) tervezett szíjhajtások különböző módon viselkednek, avagy különböző instabilitási tartománnyal bírnak valószínúleg, azonos szabad szíjág tervezési paraméterek mellett [1]. Ez föképp indokolja az eddig létező modellek pontosítását, amelyeknél csupán a transzverzális lengésre képes szabad szíjágat vették figyelembe egy teljes rendszerként. A további fejezetekben kívánom a két rendszert röviden külön-külön bemutatni, majd egy lehetséges összeillesztésüket.

\section{A kezdeti, szíjág keresztirányú lengését leíró mozgásegyenlet}

Nyilvánvaló, hogy amennyiben a szíjág keresztirányú lengését szeretnénk vizsgálni, húrként érdemes a rendszert modelleznünk. A valóságot ennél jobban megközelítő jelenségek leírása érdekében azonban Kauderer [8], Faragó [3] később Patkó [5, 10, 15] figyelembe vették a szíjág anyagának hajlítómerevségét is, ezen túl a rendszer egy húrszerúen (paraméteresen) gerjesztett Euler-Bernoulli rúd modelljére hasonlít legjobban. A viszonylag nagy, keresztirányú szijág amplitúdót feltételezve, a mozgásegyenletünk már csak emiatt is nemlineáris. További nemlinearitás jelenhet meg még a szíj anyagának feltételezett harmadfokú karakterisztikája miatt is. Az energiamennyiségek felírását követően az Euler-Lagrange-féle variációs elv és a Hamilton elv használatának eredményeképpen - továbbá néhány egyszerüsítéssel élve - kontinuum rezgéstani modellt kapunk, amely az említett szerzőpáros munkáiban is megtalálhatunk. Későbbiekben tanszékünkön, illetve számos folyóiratban foglalkoztak hasonló modellek stabilitási kérdéseivel, de teljes rendszerként pusztán a 


$$
\rho A \frac{\partial^{2} w(x, t)}{\partial t^{2}}+r \frac{\partial w(x, t)}{\partial t}+I_{y} E \frac{\partial^{4} w(x, t)}{\partial x^{4}}-\frac{\partial^{2} w(x, t)}{\partial x^{2}}\left\{\frac{A E}{L}\left[u(L, t)-u(0, t)+\frac{1}{2} \int_{x=0}^{L}\left(\frac{\partial w(x, t)}{\partial x}\right)^{2} d x\right]\right\}=0
$$

parciális csillapított integro-differenciálegyenletet, azaz a szabad szíjágat vették alapul (1. ábra). A könnyebb matematikai kezelhetőség érdekében a Galjorkin-módszer segítségével az (1)-es végtelen szabadságfokú modellböl egy véges szabadságfokú tömegpont modellt tudunk származtatni. Ezen diszkretizációs, illetve végeselemes módszer segítségével - más szavakkal élve - parciális differenciálegyenletből közönséges mozgásegyenletet tudunk származtatni, melynek eredménye a

$$
\frac{d^{2} q_{k}}{d \tau^{2}}+2 \frac{r}{\rho \Omega A} \frac{d q_{k}}{d \tau}+4\left(\frac{k \pi}{L}\right)^{2}\left\{\left(\frac{k \pi}{L}\right)^{2} \kappa(h) \frac{E}{\rho \Omega^{2}}-R_{1}^{2}+\frac{E}{\rho \Omega^{2} L}\left[u_{M}+u_{f}+e_{2} \cos (2 \tau)+\left(\frac{k \pi}{L}\right)^{2} \frac{1}{L} q_{k}^{2}\right]\right\} q_{k}=0
$$

csillapított Mathieu-Duffing-féle mozgásegyenlet, amely tartalmazza a tervezési paramétereket: $E$ a szíjanyag rugalmassági modulusa; $L$ a szíjág teljes hossza; $q_{k}$ a k-lengésképhez tartozó Lagrange-féle általánosított keresztirányú lengés koordinátája; $\tau$ a dimenziótlanított időkoordináta a peremfeltételek időtől való függésének kiküszöbölésére; $r$ a csillapítási együttható; $\kappa(h)$ egy egyszerüsített formula, amely tartalmazza a hajlítómerevség és a szíjág keresztmetszet viszonyát; $R_{1}$ az 1-es tárcsa sugara, $u_{m}+u_{f}$ az hosszirányú elmozdulások, amelyek a kezdeti előfeszítésből és a terhelő nyomatékból származnak; $\Omega$ a tárcsa körfrekvenciája; $e_{2}$ a tárcsa excentricitása, amely a paraméteres gerjesztési forrás esetünkben.

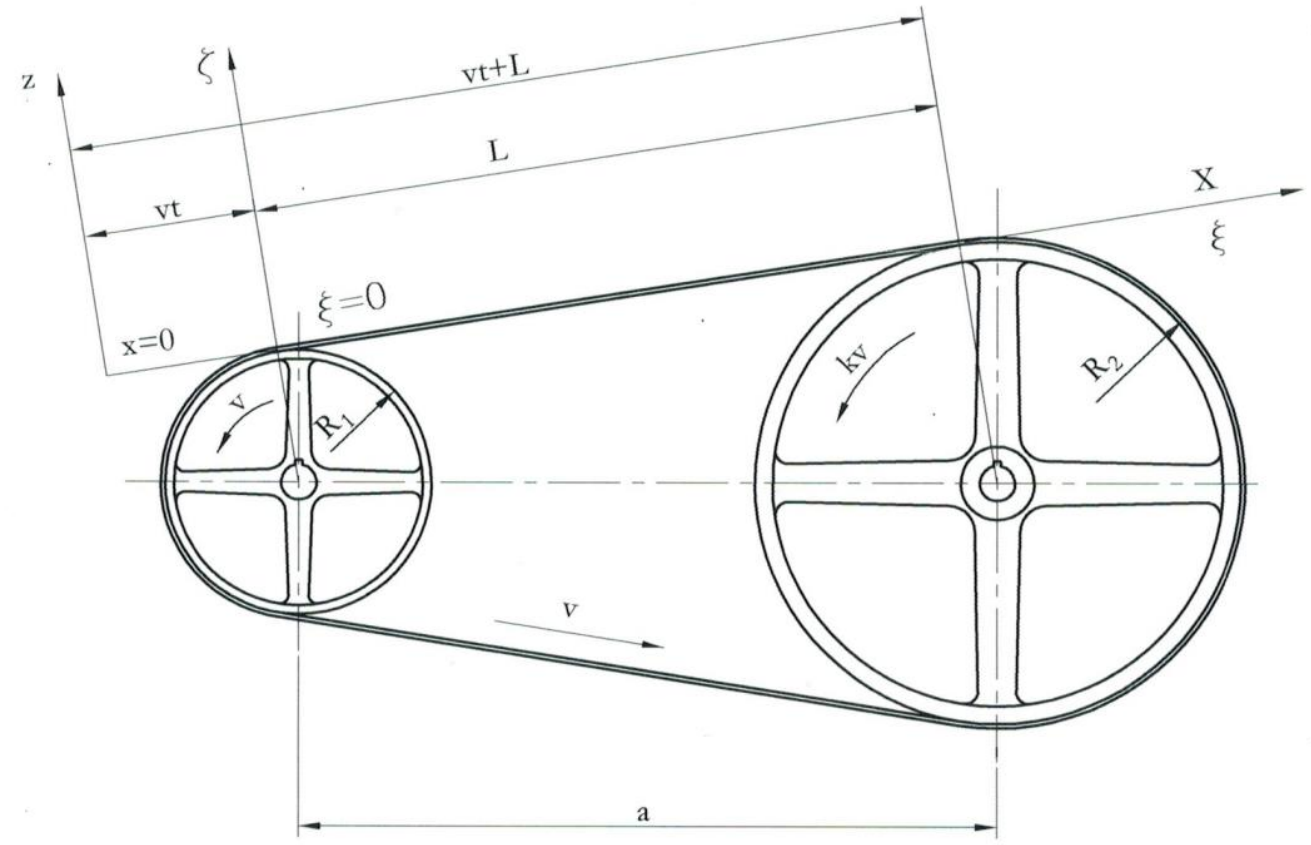

1. ábra. A hajtás modellje a koordinátatranszformáció után 


\section{A szíjtárcsa mentén lévő szíj alkotta rezgőrendszer, avagy a rugalmas-képlékeny tar- tomány figyelembevétele}

A szíjhajtások lengésével kapcsolatos szakirodalmat tanulmányozva rátaláltam egy olyan jelenség létezésére, amikor a szíjtárcsa mentén lévő szíj a szíjcsúszás előtt alakváltozást szenved [9,11]. A szíjtárcsa mentén két-három tartományt is megkülönböztetnek, a tisztán tapadási részt, amely rezgéstani szempontból elhanyagolható, továbbá a csúszás előtti alakváltozási és a megcsúszási szakaszt, amelynek már rezgéstani jelentőséget tulajdonítottam a szíjág keresztirányú lengései esetén is.

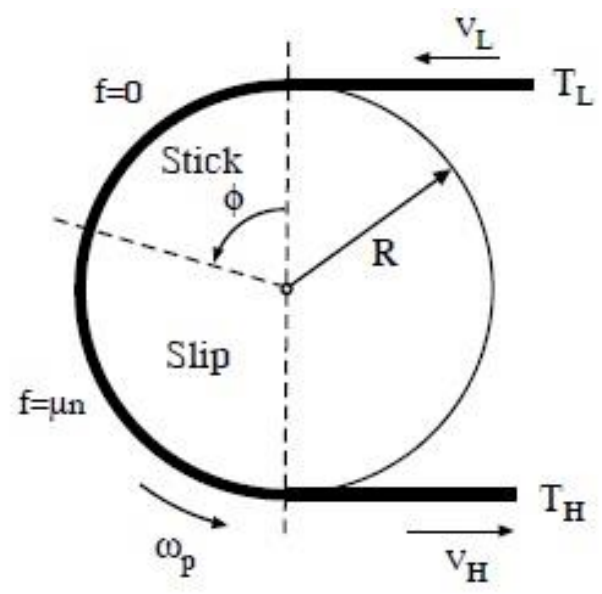

2. ábra. Tapadási és súrlódási zónák a szijtárcsán, Coulomb - féle súrlódással.

Egyes irodalmak megkülönböztetnek rugalmas részt is a tapadási és csúszási szakaszok mellett [9,11]

Ez az Elastic - Perfectly Plastic (továbbiakban EPP) súrlódási modell, amellyel számos szakirodalom foglalkozik önmagában. Felírtam az előbb említett rendszereknek a nemlineáris mozgásegyenletét a csúszás előtti és utáni tartományra, a Hamilton - elv, Euler - Lagrange - féle variációs elv, Galerkin módszer segítségével, szintén egészen az energiaszerü mennyiségektől indulva. Ugyanezt megtették az előző szerzők is, de a modell továbbfejlesztése érdekében a továbbiakban feladatunk lesz egészen az energiamennyiségektől kezdve újabb nemlinearitásokkal bíró mozgásegyenletet származtatni. Az így kapott differenciálegyenletet - terjedelmi okok miatt - az alábbi

$$
m \frac{d^{2} u(\tau)}{d \tau^{2}}+b \frac{d u(\tau)}{d \tau}+c u(\tau)=0
$$

általános összefüggésként kívánom tárgyalni, ahol az $u(\tau)$ a tárcsa mentén létrejövő szíj irányú elmozdulás dimenziótlanított általános koordinátája; az $m$ a tömeg; $b$ a csillapítási együttható; $c$ a rugómerevség, avagy a rugókarakteriszikát jellemző töréses függvény.

Ezen (3)-as rendszer erős nemlinearitásokkal bír. Az EPP súrlódási modellben szerepel egy kontinuum rugalmasság, amelyet elméletben tetszőlegesen nagy kitérés mellett is folytonos függvénnyel írhatunk le, amely lehet nemlineáris is. A másik összetevője a rugókarakterisztikának pedig egy merevtestszerủ súrlódás, amely egy erős nemlinearitást vonz magával, amely a csúszás előtti alakváltozás (microslip) és a megcsúszás (slip) jelenségét írja le. Feltételezéstől függően ezen karakterisztika (3. ábra) összetevő lehet szakaszosan lineáris - nemlineáris, vagy pedig szakaszosan nemlineáris - nemlineáris, tehát mindenképpen egy töréses karakterisztikával van többek között dolgunk. Ezt az önmagá- 
ban is bonyolult nemlineáris problémát a későbbiekben a „fázisgörbék feletti összeillesztéssel” kívánom linearizálni. Fontos, hogy ezen mozgásegyenlet rendkívül változatos lehet, attól függően, hogy milyen típusú szíjra van megalkotva. Talán ez fogja okozni a változatos viselkedését a modellnek, amit a gyakorlatban is tapasztalhatunk különböző típusú szíjak esetén.

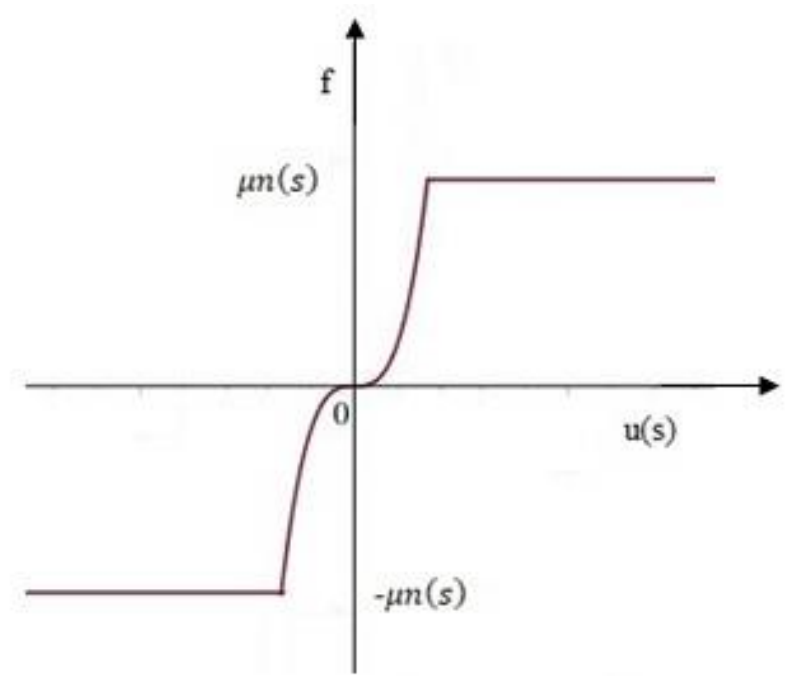

\section{3. ábra. A szakaszosan nemlineáris - nemlineáris EPP karakterisztika}

\section{A szabad szíjág és a szíjtárcsa mentén lévő rezgőrendszer összeillesztésének lehetősé- gei}

Amennyiben megkaptuk mind a szabad szíjág és a szíjtárcsa mentén lévő szíj alkotta rezgőrendszer linearizált mozgásegyenletét, valamilyen feltételezéssel össze kell kapcsolnunk őket, mivel a kiegészített rendszert kívánjuk vizsgálni (amelyet az előzőekben tárgyaltak indokolnak) a pontosabb, lehetséges új eredmények származtatása érdekében.

Tekintsük először is a szabad szijágat leíró csillapított Mathieu-Duffing-féle mozgásegyenletet [2, $6,12,13,14]$. A $q_{k}$-t, tehát a keresztirányú lengésnek az amplitúdói nagyságát, illetve instabilitási tartományait szeretnénk vizsgálni, mivel a szíjág erőteljes keresztirányú lengései okozzák a hajtás fó rezgésforrását. A húrszerü gerjesztést pedig a tárcsa excentricitásának létezéséből feltételezzük, amely esetünkben - fontos megjegyezni - longitudinális irányban hat. Egy másik fontos észrevétel/feltételezés, hogy a szíjtárcsa mentén lévő rezgőrendszer $u(\tau)$ szíj irányú dimenziótlanított általános koordinátája egybeesik az előbb említett húrszerü gerjesztés irányával.

Érdekesség tehát, hogy a Mathieu-Duffing-féle mozgásegyenlet esetén longitudinális irányú gerjesztést feltételezünk a rendszerben, viszont keresztirányú lengést kapunk megoldásul. A lengés során a továbbiakban semmiféle információt nem kapunk arról, hogy milyen erővel, illetve instabilitási tartományon kívül mekkora frekvenciával „kapnak gerjesztést” a húr modell peremei. Floquet tétele alapján azonban biztosak lehetünk abban, hogy paraméteres gerjesztés esetén a stabilitásvesztés a periodikus megoldás jelenlétét tükrözi. Ekkor tehát - a szíjág lengésképét figyelembe véve - ismerhetjük a gerjesztési frekvenciáját a húr modell peremeinek. Feltételezésem szerint ezen gerjesztő frekvencia hat a szíjtárcsa mentén lévő szíj alkotta rezgőrendszerre is, amely majd egy „felnagyított excentricitással” fog valószínüleg válaszolni a linearizált nagyítási függvényének megfelelően. Az excentricitás, mint fó gerjesztési forrás mellé tehát első közelítésben a szíjtárcsa mentén lévő rezgőrendszer nagyítási függ- 
vényét lehetne helyettesíteni a keresztirányú lengést leíró mozgásegyenletbe. Fontos megjegyezni, hogy ezzel a feltételezéssel élve a szabad szíjág, illetve a teljes rendszer instabilitási tartományait nem változtattuk meg, csupán a stabilitásvesztéskor kialakuló amplitúdókban lesz változás, mivel a két rendszer rezonanciagörbéje fog együttesen érvényre jutni. Ilyen értelmezésben tehát csupán egy módosított, szögsebességfüggő excentricitással egészült ki a rendszer. A két rendszer összeillesztésére további pontosítások, feltételezések szükségesek még a numerikus számításokon kívül, az analitikus, tervezési szakaszban is jól használható linearizált összefüggések származtatása érdekében. Ezek lehetséges további kiegészítéseivel a későbbiekben foglalkozni kívánunk.

\section{5. Összefoglalás}

A szíjhajtások dinamikai modelljének egy lehetséges pontosítására mutattunk be ötletet, amelynek segítségével a későbbiekben valószínüleg a valóságot jobban megközelítő számítási eredményeket tudunk bemutatni különböző típusú szíjhajtások esetén. Szándékunkban áll megalkotni a teljes rendszerre a linearizálás eredményeképpen származtatott analitikus összefüggéseket, amikor is a rezgörendszer minőségi jellemzői a tervezési paraméterek folytonos függvényei lesznek. Ezek az összefüggések később a gép tervezési szakaszában is fontosak lesznek, a szilárdsági számítás/ ellenőrzés mellett.

\section{Irodalom}

[1] Ottrosinka, T., Simon, G., Beleznai R.: Lapos szíjjal hajtott szerszámgép főorsók stabilitás vizsgálata, Kolozsvár, 2005.

[2] Bosznay, Á.: Müszaki Rezgéstan, Budapest, Müszaki Könyvkiadó, 1962.

[3] Faragó, K.: Szíjhajtással kombinált szerszámgép nemlineáris rezgései, Kandidátusi értekezés, Miskolci Egyetem, 1986.

[4] Takács, Gy.: Korszerü szerszámgépek, előadás anyag, Miskolci Egyetem.

[5] Patkó, Gy.: Dinamikai eredmények és alkalmazások a géptervezésben (Habilitation thesis), Miskolc, Miskolci Egyetem Habilitációs Füzetei, 1998. (In Hungarian).

[6] Den, H.: Mechanical vibrations, New York, Dover Publications, 1984.

[7] Knoll, I.: Szíj-, lánc-, kötél-és dörzshajtások, Budapest, Müszaki Könyvkiadó, 1985.

[8] Hans, K.: Nichlineare mechanic, Berlin-Göttingen-Heidelberg, Springer Verlag, 1958.

[9] Dooro, K.: Dynamic modeling of belt drives using the elastic/ perfectly plastic friction law, Georgia Institute of Technology, 2000.

[10] Patkó, Gy., Kollányi, T.: On transverse vibrations of belt, in Miskolci Egyetem, Miskolc, 2004.

[11] Leamy, M.: Analysis of belt-drive mechanics using a creeprate-dependent friction law, Journal of Applied Mechanics

[12] Loud, S.: Stability Regions for Hill's Equation, Journal of Differential Equations, vol. 19, pp. 226-241, 1974. https://doi.org/10.1016/0022-0396(75)90003-0

[13] Leonard, M.: Fundamentals of vibration, Virginia, Virginia Polytechnic Institute and State University, 2001.

[14] Rand, R.H.: Mathieu's equation, Udine, Italy, Cornell University, 2016.

[15] Kollányi, T.: Szíjágak transzverzális lengései, Miskolc, 2003.

[16] Zsáry, Á.: Gépelemek II., Budapest, Tankönyvkiadó, 1991. 